\title{
Influence of salinity soil on the sodium, potassium and calcium content of tomato Lycopersicum esculentum Mill. (Solanales Solanaceae) at 5-leaf stage
}

\author{
Arbaoui Mohamed ${ }^{\prime *}$,Yahia Noredine ${ }^{2}$ \& Ghelamallah Amine ${ }^{3}$ \\ ${ }^{1}$ Department of Biology, Faculty of Natural and Life Sciences, University Abdelhamid Ibn Badis, Mostaganem, Algeria \\ ${ }^{2}$ Department of Biology, Faculty of Natural and Life Sciences, University Ahmed Ben Bella Oran 1, Algeria \\ ${ }^{3}$ Department of Agronomy, Faculty of Natural and Life Sciences, University Abdelhamid Ibn Badis. Mostaganem. \\ Algeria \\ ${ }^{*}$ Corresponding author, e-mail: mohamed.arbaoui@univ-mosta.dz
}

\begin{abstract}
The effect of salinity $\left(\mathrm{NaClCaCl}_{2}\right)$ on the evolution of mineral ions $\left(\mathrm{Na}^{+}, \mathrm{K}^{+}\right.$and $\left.\mathrm{Ca}^{++}\right)$and the variation of $\left(\mathrm{Na}^{+} / \mathrm{K}^{+}\right.$and $\mathrm{Na}^{+} / \mathrm{Ca}^{++}$ratios $)$in the roots of a Rio grande $(\mathrm{Rg})$ tomato variety $(\mathrm{Ly}$ copersicon esculentum Mill., Solanales Solanaceae) at the 5-leaf stage was investigated. After germination of the seeds, the seedlings obtained are transferred to their environment to receive the nutritive solution. At 5 leaf stage, salt stress was applied with four concentrations $(0,100$, 200 and 300 meq L- $1 \mathrm{NaClCaCl}_{2}$ ) for 15 days. The results shows that salt stress increased $\mathrm{Na}^{+}$ and decreased $\mathrm{K}+$ content significantly in both cultivars. Increase of salinity resulted in an increase of ions $\mathrm{Na}^{+}$and $\mathrm{Ca}^{++}$in the tomato root cultivated on the two substrates but a decrease of $\mathrm{K}+$. The $\mathrm{Na}^{+} / \mathrm{K}^{+}$and $\mathrm{Na}^{+} / \mathrm{Ca}^{++}$ratio in roots of both cultivars cultivated on the two substrates increased significantly when concentration of $\mathrm{NaClCaCl}_{2}$ increased in the medium. The presence of calcium in the medium (irrigation solution and bentonite) favored an increase in the average amount of calcium ions in the roots of tomato grown in sand substrate mixed with bentonite compared to those cultivated in the sand substrate alone.
\end{abstract}

KEY WORDS Bentonite; $\mathrm{Na}^{+} ; \mathrm{K}^{+} ; \mathrm{Ca}^{++}$; Ratio; Root; Salinity; Tomato.

Received 03.06.2020; accepted 20.11.2020; published online 30.12.2020

\section{INTRODUCTION}

Tomato (Lycopersicon esculentum Mill.) (Solanales Solanaceae), one of the most important and widespread crops in the world, with total production and cultivated area estimated at $164 \mathrm{Mt}$ and 4.76 Mha, respectively (Rodriguez-Ortega et al., 2019). Tomato is sensitive to moderate levels of soil salinity which is a major abiotic constraint that negatively affects the physiological and biochemical aspects of the plant, resulting in a reduction of its yield. In Algeria, tomato production is mainly located in areas with a semi-arid Mediterranean cli- mate characterized by sandy soils and irrigation water loaded with abnormally high soluble salts. This situation causes a decrease in the yields of the tomato crop. Soil salinity impacts are not limited only to the environment but also extend to the economy (Allbed \& Kumar, 2013). This also adversely affects plant growth, crop production, soil and water quality, eventually resulting in soil erosion and land degradation (Rhoades \& Loveday, 1990; Zhu, 2001). In addition, it induces osmotic stress, physiological dryness and ionic imbalance, thereby disabling the plant's vital cellular functions (Gupta \& Huang, 2014). This constraint affects 
downward water availability, reduced respiration rate (Cramer et al., 2013), mineral salt distribution (Babu et al., 2012) and variations in turgor pressure (Shabala et al., 2012). Thus, plants trigger hormonal, physiological and biochemical mechanisms either by tolerating or resisting this constraint (Almeida et al., 2012). Salt stress influences growth through many facets of metabolism, such as nutrient uptake and distribution within the plant, alteration of photosynthesis (Taffouo et al., 2013), synthesis of proteins, accumulation of organic solutes, hormonal balance and water availability (Karuppasamy et al., 2014). In addition, the reduction in growth due to salinity is also attributable to ion toxicity and nutrient imbalance. This state causes not only an increase of accumulation of sodium $\left(\mathrm{Na}^{+}\right)$and chloride $\left(\mathrm{Cl}^{-}\right)$in plants, but also it affects antagonist of absorption of essential elements such as potassium $(\mathrm{K}+)$, calcium $\left(\mathrm{Ca}^{++}\right)$and magnesium $\left(\mathrm{Mg}^{++}\right)$with $\mathrm{Na}+$ and nitrates $\left(\mathrm{NO}_{3^{-}}\right)$ in contrast to $\mathrm{Cl}$ - (Zörb et al., 2005). The constituent cations of total soluble salts in soils are usually sodium $(\mathrm{Na}+)$, calcium $\left(\mathrm{Ca}^{++}\right)$, and magnesium $\left(\mathrm{Mg}^{++}\right)$and the anions are chloride $\left(\mathrm{Cl}^{-}\right)$and carbonate. However, $\mathrm{Na}+$ dominates the cations and $\mathrm{Cl}^{-}$the anions in the majority of saline soils to the extent that $\mathrm{NaCl}$ comprises from $50-80 \%$ of the total soluble salts (Rengasamy, 2006). Salt stress has reduced soil water potential leading to osmotic stress, induces ion imbalance in cells, especially lower concentrations of $\mathrm{K}^{+}, \mathrm{Ca}++$ and $\mathrm{NO}_{3}{ }^{-}$, and causes ion $\left(\mathrm{Na}^{+}\right.$and/or $\left.\mathrm{Cl}^{-}\right)$toxicity (Munns \& Tester, 2008). Reduced $\mathrm{Na}+$ loading into the xylem is one of the main mechanisms of salinity tolerance and it is often considered one of the most crucial features of restricting $\mathrm{Na}^{+}$accumulation in plant tissues (Munns \& Tester, 2008). Thus, our research experiment investigated the effect of osmotic stress of salinity on the sodium, potassium and calcium contents, alterations in $\mathrm{Na}^{+} / \mathrm{K}^{+}$and $\mathrm{Na}^{+} / \mathrm{Ca}^{++}$in root of tomato plants cultivated on the two different substrates at 5 leaves level.

\section{MATERIAL AND METHODS}

\section{Plant materials and culture mode}

Processing tomato (Lycopersicon esculentum) variety "Rio Grande" (Rg) was used as plant mate- rial for this experience. The crop is grown in two different types of substrate: sand $(\mathrm{S})$ and sand mixed with $10 \%$ of bentonite (SB). The substrate is placed in plastic pots of $15 \mathrm{~cm}$ diameter and $17 \mathrm{~cm}$ height with a capacity of $1.3 \mathrm{~kg}$.

\section{Preparation of the culture substrate}

The sand is washed beforehand with dilute hydrochloric acid, rinsed thoroughly with distilled water to remove the chlorides and dried in an oven at $105^{\circ} \mathrm{C}$. Thus prepared, the sand constitutes a support of the plant, allows aeration of the roots and has the advantage of not fixing the ions (Demolon, 1968). After natural drying, the bentonite (clay of calcium origin) is crushed then mixed with the sand with a dose of $10 \%$. The Sand-Bentonite mixture is carefully homogenized manually, then filled into the pots. Beforehand the bottom of the pots is lined with a layer of one $\mathrm{cm}$ thick gravel of $0.5 \mathrm{~cm}$ in diameter serving as drains. On this layer a gas strip is deposited to retain the sand. After germination, the plants was transplanted at the rate of one plant per pot, which constitutes an experimental unit repeated three times, followed by irrigation with the nutrient solution (Hoagland \& Arnon, 1938). The saline stress was composed of four concentrations (Control, 100, 200 and 300 meq.L $\mathrm{L}^{-1}$ of $\mathrm{NaClCaCl}_{2}$ ), the control is sprinkled with the nutritive solution. Stress was applied on the 40th day of sowing, i.e. at the 5-leaf stage, then repeated at a frequency of three times a day until 55th day. A week later, the samples are taken to undergo mineral analysis $\left(\mathrm{Na}^{+}\right.$, $\mathrm{K}^{+}$and $\mathrm{Ca}^{++}$) in the roots.

\section{Mineral ions}

Three plants per treatment are taken, after a passage in the oven at $80^{\circ} \mathrm{C}$ for 24 hours, the roots underwent an analysis of the various minerals. The assay is carried out in medium composed of $\mathrm{H}_{2} \mathrm{O}_{2}$ and $\mathrm{HClO}_{4}$ from $0.5 \mathrm{~g}$ of ash placed in $100 \mathrm{ml}$ flasks, to which 12.5 of hydrogen peroxide $\left(\mathrm{H}_{2} \mathrm{O}_{2}\right)$ are added. After overnight rest, perchloric acid $\mathrm{HClO}_{4}$ is added. Flasks are placed on a ramp and gently heated, then gradually cools. Then the distilled water is added to $100 \mathrm{ml}$. The assay is performed by a flame spectrophotometer. The percentage of each element is calculated by the following formula: 
$\%\left(\mathrm{Na}^{+}, \mathrm{K}^{+}\right.$and $\left.\mathrm{Ca}^{++}\right)=(n / \mathrm{D}) *\left(\mathrm{~V} / 10^{4}\right) * \mathrm{~W}=$ in g. $100 \mathrm{~g}^{-1}$ of DW.

$n$ : a gluanometric number, D: dilution $=1, \mathrm{~V}$ : extraction volume $=100 \mathrm{ml}, \mathrm{W}$ : sample weight.

\section{Statistical analysis}

An experimental design of plots in complete random blocks was carried out using 3 plants per treatment. Three roots and three stems per plant were sampled for anatomical studies. Data were analyzed by ANOVA using the Newman-Keuls Least Significant Difference Test (LSD) for mean comparisons using a significance level of $5 \%$.

\section{RESULTS}

Figure 1 shows the effect of soil salinity on the $\mathrm{Na}+$ content of the roots. However, the low $\mathrm{Na}^{+} \mathrm{val}-$ ues are recorded in the control plants with 1.78 mg. $100 \mathrm{~g}^{-1} \mathrm{DW}$ in the substrate $\mathrm{S}$ and $(1.8 \mathrm{mg} .100$ $\mathrm{g}^{-1} \mathrm{DW}$ ) in the substrate SB; as soon as the salinity increases in the culture medium, the $\mathrm{Na}+$ increases in the roots to give significant values to 300 meq of $\mathrm{NaClCaCl}_{2}$ of 7.1 and $6.73 \mathrm{mg} .100 \mathrm{~g} \mathrm{~g}^{-1}$ of DW respectively in the S and SB (Table 1). Under the highest salinity (300 meq), the $\mathrm{Na}^{+}$reaches $(74.85 \%)$ in the substrate $\mathrm{S}$ and $(73.26 \%)$ in the SB compared to the control. The two-factor ANOVA reveals a significant effect of salinity, but not significant effect at $\mathrm{P}<0.05$ of the substrate and salinity times substrate interaction (Table 1). The content of $\mathrm{K}^{+}$root decreases appreciably with increasing salt stress and in the two culture substrates (Fig. 1). The plants cultivated respectively in the substrates $S$ and $\mathrm{SB}$ record values passing from 3.37 and $3.47 \mathrm{mg}$. $100 \mathrm{~g} \mathrm{~g}^{-1}$ of DW in the control to 2.8 and $3.2 \mathrm{mg} .100$ $\mathrm{g}^{-1}$ of DW under 300 meq of $\mathrm{NaClCaCl}_{2}$. The $\mathrm{K}^{+}$ values in the roots decrease respectively to $300 \mathrm{meq}$ of $\mathrm{NaClCaCl}_{2}$ by $16.83 \%$ in the $\mathrm{S}$ and by $7.77 \%$ in the SB (Table 1). The two-factor analysis of variance reveals a not significant at $\mathrm{P}<0.05$ of the treatment salinity, the substrate and the salinity-substrate interaction on the $\mathrm{K}+$ ion (Table 1). The $\mathrm{Na}+/ \mathrm{K}+$ ratio in tomato roots increases in saline environment. At 300 meq.L-1 of $\mathrm{NaClCaCl}_{2}$, the roots cultivated in the substrate $\mathrm{S}$ record a rate of $79.36 \%$, this ratio increases slightly in the roots raised in the substrate SB to reach $76.31 \%$ (Table 1) The analysis of the variance with two factors reveals significant effect at $\mathrm{P}<0.05$ of salinity, substrate and interaction salinity times substrate on the $\mathrm{Na}+/ \mathrm{K}+$ ratio (Table 1).

Figure 2 shows that the calcium content of the roots decreases considerably under the effect of salt stress. The two substrates S and SB record respectively in the control plants 2.906 and $3.5 \mathrm{mg} 100 \mathrm{~g}$ 1 of DW, these contents drop to 2.1, 0.92 and 0.52 $\mathrm{mg} 100 \mathrm{~g}-1 \mathrm{DW}$ and 2.9, 1.55 and $1.42 \mathrm{mg} 100 \mathrm{~g}-$ 1 DW respectively at 100, 200 and 300 meq.L-1 of $\mathrm{NaClCaCl}_{2}$ (Table 2). By comparing the two culture substrates, the calcium content of the roots decreased in the substrate $\mathrm{S}$ by $82.13 \%$ and $59.42 \%$ in the SB in the control compared to plants stressed with 300 meq.L-1 of $\mathrm{NaClCaCl}_{2}$ (Table 2). Analysis of the variance shows a significant effect of the salinity and the substrate on $\mathrm{Ca}^{++}$, but, no significant effect of the interaction salinity times substrate (Table 2). On the other hand, the selective $\mathrm{Na}^{+} / \mathrm{Ca}^{++}$ ratio in the roots of the tomato increases under the effect of salt stress (Fig. 2). The lowest rates are recorded in the control roots with 0.611 and 0.517 respectively in the S and the SB. However, when the salinity increases in the culture medium, these rates increase at 13.6 and 4.73 successively in the substrate $\mathrm{S}$ and $\mathrm{SB}$, these ratios increased by $95.5 \%$ in the $\mathrm{S}$ and by $89.06 \%$ in the SB (Table 2). The statistical study at $\mathrm{P}<0.05$ showed a very significant effect of the salinity, the substrate and the interaction between the treatment substrate (Table 2).

\section{DISCUSSION}

Plants grown in a saline environment accumulate more sodium than potassium ions (Sudhir \& Murthy, 2004). Generally, increased sodium accumulation causes potassium deficiency in plants stressed by salt, which indicates the existence of competitive effects between sodium and potassium ions (Maggio et al., 2007). Salt stress resulted in an increase in $\mathrm{Na}^{+}$ions and a decrease in $\mathrm{K}^{+}$ions in the roots. The increase in $\mathrm{Na}^{+}$in the roots decreases the osmotic potential, thus helping to maintain the difference in water potential between the roots and the medium necessary to obtain water from the saline solution. $\mathrm{Na}^{+}$competes with $\mathrm{K}^{+}$at entry sites and ultimately decreases the absorption of $\mathrm{K}^{+}$(Shabala et al., 2003). The ionic response of 
the plant in saline medium is the reduction of the accumulation of $\mathrm{K}^{+}$, by replacing $\mathrm{K}^{+}$by $\mathrm{Na}^{+}$, which causes an ionic imbalance (Nedjimi \& Daoud 2009). This competition can have significant negative effects on plant development and growth, where $\mathrm{Na}^{+}$levels often exceed those of $\mathrm{K}^{+}$(Tester \& Davenport 2003). With other solutions, $\mathrm{K}^{+}$plays a major role in osmotic adjustment, the maintenance of turgor and, thus, the attenuation of the harmful effect of saline stress (Wang et al., 2013). However, figure 1 shows the effect of salinity on the $\mathrm{Na}^{+} / \mathrm{K}^{+}$ratio, according to Alleva et al. (2006) and Akram et al. (2007), the high $\mathrm{Na}^{+}$concentration decreases the intracellular influx of $\mathrm{K}^{+}$. Therefore, maintaining a low $\mathrm{Na}^{+} / \mathrm{K}^{+}$ratio in cells is essential for plant tolerance to salt stress (Maathuis \& Amtmann, 1999). In addition, there is a physiological relationship between ionic accumulation in the plant organ, the evolution of the selective relationship and the mechanisms of tolerance to salinity (Noble et al., 1984; Munns \& Tester, 2008; Gupta \& Huang, 2014). One of the mechanisms of

\begin{tabular}{|c|c|c|c|c|}
\hline Substrate & Salinity & $\mathrm{Na}^{+}$ & $\mathrm{K}^{+}$ & $\mathrm{Na}^{+} / \mathrm{K}^{+}$ \\
\hline Sand & $100 \mathrm{meq}$ & $3.233^{\mathrm{b}}$ & $3.233^{\mathrm{e}}$ & $0,999^{\mathrm{g}}$ \\
\hline Sand & $200 \mathrm{meq}$ & $5.067^{\mathrm{c}}$ & $3.17^{\mathrm{e}}$ & $1.6^{\mathrm{h}}$ \\
\hline Sand & $300 \mathrm{meq}$ & $7.067^{\mathrm{d}}$ & $2.8^{\mathrm{e}}$ & $2.52^{\mathrm{i}}$ \\
\hline Sand & Control & $1.777^{\mathrm{a}}$ & $3.367^{\mathrm{e}}$ & $0.52^{\mathrm{f}}$ \\
\hline \multicolumn{2}{|r|}{ Percent change } & $74.85 \%$ & $16.83 \%$ & $79.36 \%$ \\
\hline SWB & $100 \mathrm{meq}$ & $4.067^{b}$ & $3.387^{\mathrm{e}}$ & $0.743^{f}$ \\
\hline SWB & $200 \mathrm{meq}$ & $5.5^{\mathrm{c}}$ & $3.31^{\mathrm{e}}$ & $1.22^{\mathrm{j}}$ \\
\hline SWB & $300 \mathrm{meq}$ & $6.733^{d}$ & $3.203^{\mathrm{e}}$ & $2.027^{\mathrm{k}}$ \\
\hline SWB & Control & $1.800^{\mathrm{a}}$ & $3.473^{\mathrm{e}}$ & $0.48^{\mathrm{f}}$ \\
\hline \multicolumn{2}{|r|}{ Percent change } & $73.26 \%$ & $7.77 \%$ & $76.31 \%$ \\
\hline Salinity & LSD at $5 \%$ & $0.0000 * * *$ & $0.273 \mathrm{~ns}$ & $0.0000 * * *$ \\
\hline Substrate & LSD at $5 \%$ & $0.159 \mathrm{~ns}$ & $0.195 \mathrm{~ns}$ & $0.000042 * * *$ \\
\hline $\begin{array}{l}\text { Salinity } \mathrm{x} \\
\text { Substrate }\end{array}$ & LSD at $5 \%$ & $0.103 \mathrm{~ns}$ & $0.887 \mathrm{~ns}$ & $0.0404 *$ \\
\hline
\end{tabular}

Table 1. Two-factor ANOVA mixed randomly with alpha $=5 \%, \mathrm{Na}^{+}, \mathrm{K}^{+}\left(\mathrm{mg} 100 \mathrm{~g}-1\right.$ of DW) and $\mathrm{Na}^{+} / \mathrm{K}^{+}$ratio in tomato roots grown on two substrates $(\mathrm{S}$ and $\mathrm{SB}$ ) stressed with $\mathrm{NaClCaCl} 2$ at the 5-leaf stage; ns: not significant at $\mathrm{P}<0.05$; *, **, $* * *$ significant at $\mathrm{P}<0.05,0.01$, and 0.001 respectively. Mean differences between substrate and stress is significant at $\mathrm{P}<$ $0.05,0.01$, and 0.001 respectively. Interaction substrate versus stress is significant at 0.05 and 0.01 respectively. Different letters are significantly different $(\mathrm{P}<0.05)$. 
tolerance to salinity is obtained with the absorption and accumulation of inorganic ions, mainly $\mathrm{Na}^{+}$, $\mathrm{K}^{+}$and $\mathrm{Cl}^{-}$(Munns \& Tester, 2008). The regulation of ions is an essential factor in the salt tolerance mechanism of tomatoes (Shabala et al., 2010).

An excess of $\mathrm{NaCl}$ causes a $\mathrm{Ca}^{++}$deficiency in the tomato roots. Plants subjected to saline stress see their calcium content decrease (Arshi et al., 2010). The decrease in calcium can be attributed to the competition of $\mathrm{Na}^{+}$and $\mathrm{Ca}^{++}$ions for binding sites (Kaya \& Higgs, 2003). Maintaining an ade- quate supply of calcium in soil saline solutions is an important factor in controlling the severity of specific ionic toxicities, especially in crops susceptible to damage by sodium and chloride (Maas, 1993; Grattan \& Grieve, 1999). The amendment of the bentonite growing medium decreased the $\mathrm{Na}+$ content in the roots. The presence of calcium improves the metabolism of other nutrients and regulates enzymatic and hormonal functions, while acting as a secondary messenger in the response to stress, it can reduce the excessive absorption of $\mathrm{Na}^{+}$

\begin{tabular}{|c|c|c|c|c|}
\hline Substrate*** & Salinity*** & $\mathrm{Na}^{+}$ & $\mathrm{Ca}^{++}$ & $\mathrm{Na}^{+} / \mathrm{Ca}^{++}$ \\
\hline Sand & $100 \mathrm{meq}$ & $3.233^{\mathbf{b}}$ & $2.1^{\mathrm{f}}$ & $1.55^{\mathrm{k}}$ \\
\hline Sand & $200 \mathrm{meq}$ & $5.067^{\mathrm{c}}$ & $0.92^{\mathrm{g}}$ & $5.56^{1}$ \\
\hline Sand & $300 \mathrm{meq}$ & $7.067^{\mathrm{d}}$ & $0.52^{\mathrm{g}}$ & $13.6^{\mathrm{m}}$ \\
\hline Sand & Control & $1.777^{\mathrm{a}}$ & $2.91^{\mathrm{e}}$ & $0.611^{\mathrm{k}}$ \\
\hline \multicolumn{2}{|r|}{ Percent change } & $74.85 \%$ & $82.13 \%$ & $95.5 \%$ \\
\hline SB & $100 \mathrm{meq}$ & $4.067^{b}$ & $2,9^{i}$ & $1,4^{\mathrm{k}}$ \\
\hline SB & $200 \mathrm{meq}$ & $5.5^{\mathrm{c}}$ & $1.55^{\mathrm{j}}$ & $3.55^{\ln }$ \\
\hline SB & $300 \mathrm{meq}$ & $6.733^{d}$ & $1.42^{\mathrm{j}}$ & $4.73^{10}$ \\
\hline SB & Control & $1.800^{\mathrm{a}}$ & $3.5^{\mathrm{h}}$ & $0.517^{\mathrm{k}}$ \\
\hline \multicolumn{2}{|r|}{ Percent change } & $73.26 \%$ & $59.42 \%$ & $89.06 \%$ \\
\hline Salinity & LSD at $5 \%$ & $0.0000 * * *$ & $0.00000 * * *$ & $0.00000 * * *$ \\
\hline Substrate & LSD at $5 \%$ & $0.159 \mathrm{~ns}$ & $0.00000 * * *$ & $0.00000 * * *$ \\
\hline $\begin{array}{l}\text { Salinity } \mathrm{x} \\
\text { Substrate }\end{array}$ & LSD at $5 \%$ & $0.103 \mathrm{~ns}$ & $0.715 \mathrm{~ns}$ & $0.00000 * * *$ \\
\hline
\end{tabular}

Table 2. Two-factor ANOVA mixed randomly with alpha $=5 \%, \mathrm{Na}^{+}, \mathrm{Ca}^{++}\left(\mathrm{mg} 100 \mathrm{~g}-1\right.$ of DW) and $\mathrm{Na}^{+} / \mathrm{Ca}^{++}$ratio in tomato roots grown on two substrates ( $\mathrm{S}$ and $\mathrm{SB}$ ) stressed with $\mathrm{NaClCaCl} 2$ at the 5-leaf stage; ns: interaction substrat vs stress non significative. *: mean differences for all effects were significant at $\mathrm{P}<0.05,0.01$, and 0.001 respectively. ${ }^{*}, * *$, $* * *$ : differences between substrate is significant at $\mathrm{P}<0.05,0.01,0.001$ respectively. The same letters are not significant at $\mathrm{P}<0.05$. 


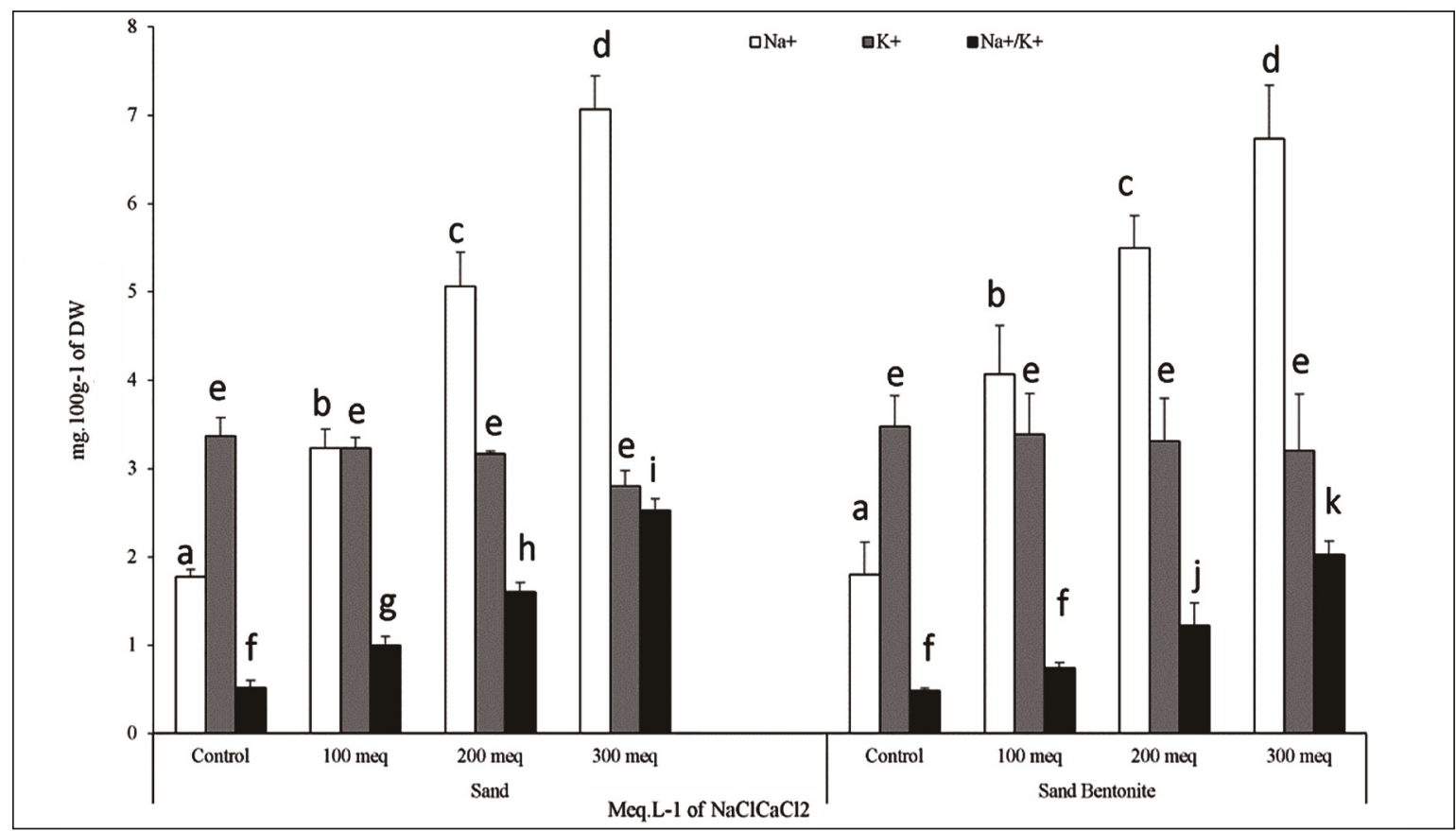

Figure 1. $\mathrm{Na}^{+}, \mathrm{K}^{+}\left(\mathrm{mg} .100 \mathrm{~g}-1\right.$ of DW) and $\mathrm{Na}^{+} / \mathrm{K}^{+}$ratio in the tomato (Lycopersicon esculentum) plants roots grown on two substrates (sand and sand mixed with bentonite) under $\mathrm{NaClCaCl}_{2}$ stress at the 5-leaf stage. Data represent the mean of tree replication and error bars indicate SD. Different letters are significantly different $(\mathrm{p}<0.05)$. ${ }^{*}, * *$ : Differences between substrate is significant at $\mathrm{P}<0.05$, and 0.01 respectively, the same letters are not significant at $\mathrm{P}<0.05$.

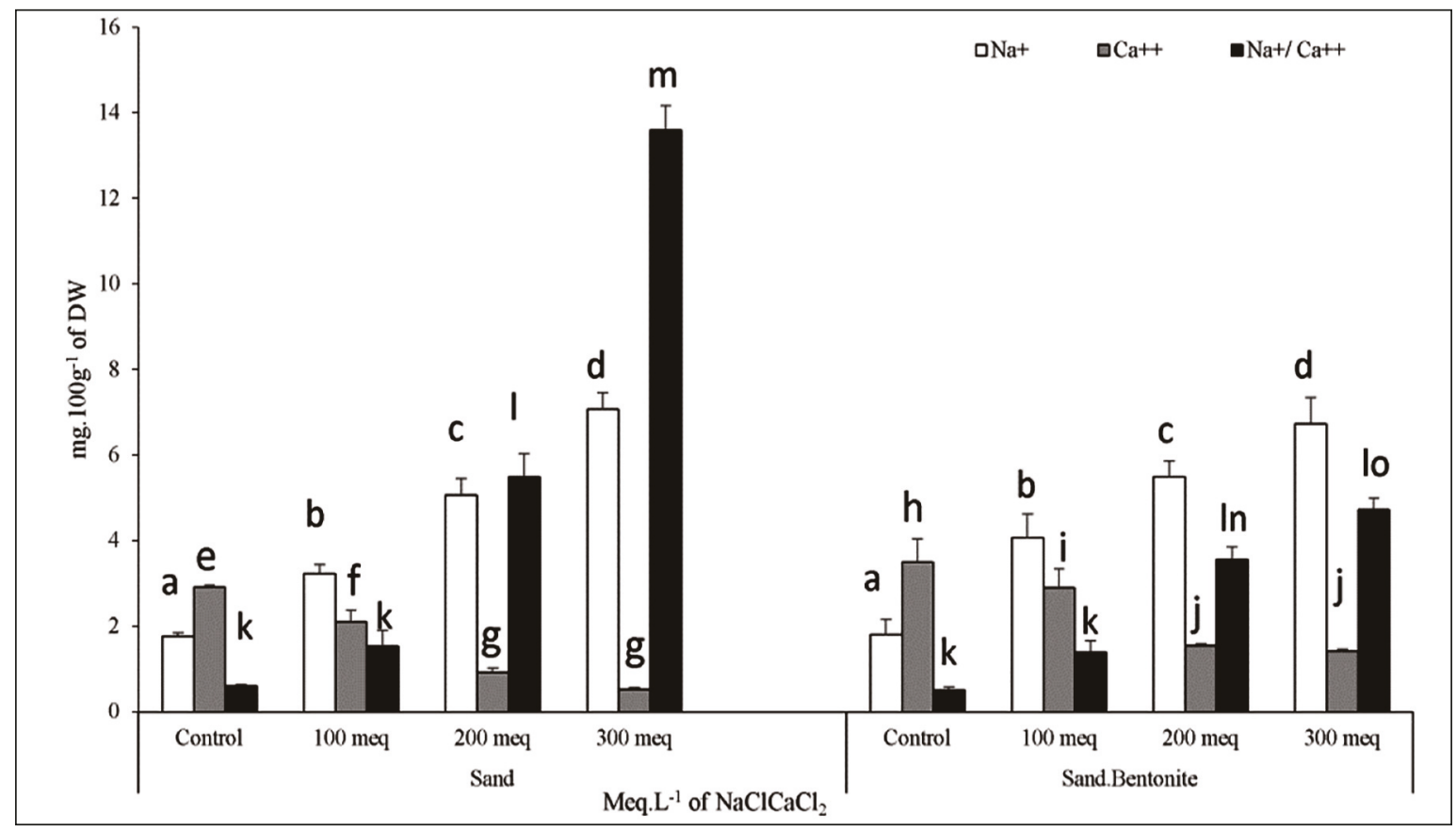

Figure 2. $\mathrm{Na}^{+}, \mathrm{Ca}^{++}$(mg.100 g-1 of DW) and $\mathrm{Na}^{+} / \mathrm{Ca}^{++}$in the tomato (Lycopersicon esculentum) plants roots grown on two substrates $\left(\mathrm{S}\right.$ and $\mathrm{SB}$ ) under $\mathrm{NaCl}+\mathrm{CaCl}_{2}$ stress at the 5-leaf stage. Data represent the mean of tree replication and error bars indicate standard deviation (SD). Different letters are significantly different $(\mathrm{p}<0.05)$. The same letters are not significant at $\mathrm{P}<0.05$. 
from plants cultivated in a saline environment (White \& Broadley, 2003). The $\mathrm{Na}^{+} / \mathrm{Ca}^{++}$ratio decreased in bentonite compared to sand alone under the effect of high salt concentrations. Calcium bentonite has helped tomato roots adapt to salt stress by reducing the toxic effects of $\mathrm{NaCl}$ and its contribution to sandy soils may have reduced the harmful effects of salinity.

\section{CONCLUSIONS}

The amendment of the sand with bentonite made it possible to see a correct ionic supply of the plant by the roots placed in a control medium, and completely eliminates the inhibitory effects of the salt on growth: it is therefore the salt of the medium which disturbs the mineral diet of the plant. We deduce that bentonite makes more nutrients and water available to the culture than the sandy substrate because of the leaching linked to the permeability of the sand which retains less nutrients than the mixture bentonized sand. In general, the tomato variety reacts to $\mathrm{NaClCaCl}_{2}$, and it is the concentration of $300 \mathrm{meq}^{-1}$ which strongly influences all of the two substrates. Adding bentonite to the sand has reduced the effect of the salt.

\section{REFERENCES}

Akram M., Malik M.A., Ashraf M.Y., Saleem M.F. \& Hussain M., 2007. Competitive seedling growth and $\mathrm{K} / \mathrm{Na}$ ratio in different maize (Zea mays L.) Hybrids under salinity stress. Pakistan Journal of Botany, 39: 2553-2563.

Allbed A. \& Kumar L., 2013. Soil salinity mapping and monitoring in arid and semi-arid regions using remote sensing technology: a review. Advances in Remote Sensing, 2: 373-385. https://doi.org/10.4236/ ars.2013.24040

Alleva K., Niemietz C.M., Sutka M., Maurel C., Parisi M., Tyerman S.D. \& Amodeo G., 2006. Plasma membrane of Beta vulgaris storage root shows high water channel activity regulated by cytoplasmic $\mathrm{pH}$ and a dual range of calcium concentrations. Journal of experimental botany, 57: 609-621. https://doi.org/10. 1093/jxb/erj046. Epub 2006 Jan 5.

Almeida A.M., Parreira J.R., Santos R., Duque A.S., Francisco R., Tomé D.F., Pinto Ricardo C., Coelho A.V. \& Fevereiro P., 2012. A proteomics study of the induction of somatic embryogenesis in Medicago truncatula using 2DE and MALDI-TOF/TOF. Physiologia plantarum, 146: 236-249. https://doi.org/ 10.1111/j.1399-3054.2012.01633.x

Arshi A., Ahmad A. Aref I.M. \& Iqbal M., 2010. Calcium interaction with salinity-induced effects on growth and metabolism of soybean (Glycine max L.) cultivars. Journal of Environmental Biology, 31: 795-801

Babu M.A., Singh D. \& Gothandam K.M., 2012. The effect of salinity on growth, hormone and mineral elements in leaf and fruit of tomato cultivar PKM1. Journal of Animal \& Plant Sciences, 22: 159-164.

Cramer G.R., Van Sluyter S.C., Hopper D.W., Pascovici D., Keighley T. \& Haynes P.A., 2013. Proteomic analysis indicates massive changes in metabolism prior to the inhibition of growth and photosynthesis of grapevine (Vitis vinifera L.) in response to water deficit. BMC Plant Biology, 13: 49. https://doi.org/ 10.1186/1471-2229-13-49

Demolon A., 1968. Croissance des végétaux cultivés. Ed Dunod, 6ème Edition, Tome II, Paris, 520 pp.

Grattan S.R. \& Grieve C.M., 1999. Mineral nutrient acquisition and response by plants grown in saline environments. Handbook of plant and crop stress, 2: 203-229.

Gupta B. \& Huang B., 2014. Mechanism of salinity tolerance in plants: physiological, biochemical, and molecular characterization. International Journal of Genomics, Article ID 701596, 18 pp. https://doi.org/ 10.1155/2014/701596

Hoagland D.R. \& Arnon D.I., 1938. Synthetic media for hydroponic culture. California Agricultural Experiment Public, 347: 35-37.

Karuppasamy K.S., Kumar S.R., Krishnakumar S., Varshini V., Susithra N., Kavitha S. \& Rajendran V., 2014. Effect of Sodium Chloride on Soluble Protein, Nitrate Reductase Activity, Proline and Catalase Enzyme Activity of Green Gram Cultivars (Co6 And Co8). Legume Genomics and Genetics, 5(5). https:// doi.org/10.5376/lgg.2014.05.0005

Kaya C. \& Higgs D., 2003. Supplementary potassium nitrate improves salt tolerance in bell pepper plants. Journal of Plant Nutrition, 26: 1367-1382.

Maas E.V., 1993. Salinity and citriculture. Tree physiology, 12: 195-216.

Maathuis F.J. \& Amtmann A.N.N.A., 1999. $\mathrm{K}^{+}$nutrition and $\mathrm{Na}^{+}$toxicity: the basis of cellular $\mathrm{K}^{+} / \mathrm{Na}^{+}$ratios. Annals of Botany, 84: 123-133.

Maggio A., Raimondi G,. Martino A. \& De Pascale S., 2007. Salt stress response in tomato beyond the salinity tolerance threshold. Environmental and Experimental Botany, 59: 276-282. https://doi.org/10.1016 /j.envexpbot.2006.02.002

Munns R. \& Tester M., 2008. Mechanisms of salinity tolerance. Annual Review of Plant Biology, 59: 651681. 
Nedjimi B. \& Daoud Y., 2009. Cadmium accumulation in Atriplex halimus subsp. schweinfurthii and its influence on growth, proline, root hydraulic conductivity and nutrient uptake. Flora-Morphology, Distribution, Functional Ecology of Plants, 204: 316-324.

Noble C.L., Hallorang M. \& West D.W., 1984. Identification and selection for salt tolerance in lucerne (Medicago sativa L.). Australian Journal of Agricultural Research, 35: 239-252

Rengasamy P., 2006. World salinization with emphasis on Australia. Journal of Experimental Botany, 57: 1017-1023.

Rhoades J.D. \& Loveday J., 1990. Salinity in irrigated agriculture. Agronomy, 30: 1089-1142.

Rodríguez-Ortega W.M., Martínez V., Nieves M., Simón I., Lidón V., Fernandez-Zapata J. C., Martinez-Nicolas J.J., Cámara-Zapata J.M. \& García-Sánchez F., 2019. Agricultural and physiological Responses of tomato plants Grown in Different Soilless Culture systems with saline Water under Greenhouse Conditions. Scientific reports, 9: 1-13.

Shabala S., Shabala L. \& Van Volkenburgh E., 2003. Effect of calcium on root development and root ion fluxes in salinized barley seedlings. Functional plant biology, 30: 507-514.

Shabala S., Shabala S., Cuin T.A., Pang J., Percey W., Chen Z., Conn S., Eing C. \& \& Wegner L.H., 2010. Xylem ionic relations and salinity tolerance in barley. The Plant Journal, 61: 839-853. https://doi.org/10. 1111/j.1365-313X.2009.04110.x
Shabala S. \& Munns R., 2012. Salinity stress: physiological constraints and adaptive mechanisms. Plant stress physiology, 1: 59-93.

Sudhir P. \& Murthy S. D. S., 2004. Effects of salt stress on basic processes of photosynthesis. Photosynthetica, 42: 481-486.

Taffouo V.D., Nouck A.H., Dibong S.D. \& Amougou A., 2013. Effects of salinity stress on seedlings growth, mineral nutrients and total chlorophyll of some tomato (Lycopersicum esculentum L.) cultivars. African Journal of Biotechnology, 9: 53665372.

Tester M. \& Davenport R., 2003. $\mathrm{Na}^{+}$tolerance and $\mathrm{Na}^{+}$ transport in higher plants. Annals of Botany, 91: 503527.

Wang Z., Gao M., Wang Z., She Z., Chang Q., Sun C., Zhang J., Ren Y. \& Yang N., 2013. Effect of salinity on extracellular polymeric substances of activated sludge from an anoxic-aerobic sequencing batch reactor. Chemosphere, 93: 2789-2795. https://doi.org/ 10.1016/j.chemosphere.2013.09.038

White P.J. \& Broadley M.R., 2003. Calcium in plants. Annals of Botany, 92: 487-511.

Zhu J.K., 2001. Plant salt tolerance. Trends in plant science, 6: 66-71.

Zörb C., Noll A., Karl S., Leib K. \& Yan F., 2005. Molecular characterization of $\mathrm{Na}+\mathrm{H}+$ antiporters (ZmNHX) of maize (Zea mays L.) and their expression under salt stress. Journal of Plant Physiology, 162: 55-66. 